\title{
A Study Examining the Effect of Pistachio Export in Iran
}

\author{
${ }^{1}$ Safdari Mehdi, ${ }^{2}$ Motiee Reza* \\ 1University of Qom, Iran \\ ${ }^{2}$ Department of Economics, Babol Branch, Islamic Azad University, Babol, Iran \\ *rm.search2011@gmail.com
}

\begin{abstract}
Pistachio is one of the most important agricultural sector products in Iran. This product is important because of creating exchange, employment, value added and other economic conditions. The purpose of this study is to determine the relationship between pistachio export and economic growth in Iran. The theoretical framework was designed based on this assumption that the total production in the economy is divided into two sections: production for inside and production for export. The data were collected from 1990 to 2003 and were analyzed using Auto Regressive Distributed Lag (ARDL) model. The result of the analyses showed that there was significant relationship between pistachio export and economic growth. Together the independent variables explained $89 \%$ of the variance in the dependent variables. The remaining $11 \%$ was due to unidentified variables. In relation to that, we can conclude that explanatory power is high for the equation. It showed that one percent change in pistachio export rate lead to $38 \%$ in economic growth. Therefore pistachio export is regarded as an important factor in Iran's economic growth.
\end{abstract}

Keywords: Augmented Dickey Fuller (ADF), Auto Regressive Distributed Lag (ARDL), GDP

\section{Introduction}

Increasing non-oil exports is the most important measures in the field reduced dependent, country to oil revenues. Creating new fields and increase employment levels in different parts of the economy (Agriculture, industry, mining and etc) improve product quality and capability the competitive and the use of unused production capacity are the factors that make important need to develop non-oil exports. Exports jump in five years of economic development - social is the main objectives of the only will be accessible using all the relative advantages and in different economic sectors, and planning efforts to maintain export markets and penetrate target markets. During the past years, agricultural products and traditional having had the largest share in non-oil exports and is necessary research into factors that may affect the export sector due to its potential, considerable resources, soils suitable for agriculture, less dependent technology in Production and volatile currency. In this case, Pistachio exports in recent years has a special place in global production, the cultivation, the world's pistachio exports, total export value of agriculture and the total value of non oil exports as a strategic product and share 50,74,68,25,7.8 percent.

In the years after the revolution Iran's pistachio exports was weak position due to cut Iran's exports to America, despite the war and reconstruction after complex global economy and most countries in the world to join the World Trade Organization (WTO). Thus with the loss of major export market of Iranian pistachio, Pistachio's largest customer became the first competitor in the global market so that world exports of pistachio in Iran during 1991 and 2002 the share was reduced from 79 to 52 percent but America's share rose from 5 to 16 percent .So, according to situation in Iran pistachio exports, especially in the later years of the revolution, comparative advantage in exports of these products can be give useful information to planners and policy makers in field of developing export strategies. Although Iran has had the advantage of years ago in some agricultural products and strong export potential, but do not keep pace with global developments in operation and have a special place.

Status of Iran's pistachio production and cultivation than world: Iran has been had largest producer of pistachios in the world that always has been had part of the production, cultivation thus with the loss of culture, the value of world exports and was allocated to own. Based on information of world Food and Agriculture Organization (FAO), Pistachio cultivation in the world is changing and has been the most bullish and from 1990 to 2003 during thirteen-year, Pistachio cultivation World has been variable so that in this period lowest value of cultivation has been 275 thousand hectares in 1990 and maximum with 440 thousand hectares in 2002 that has been growth equal to 37 percent than start course review. Between countries in the world, with 285 thousand hectares of pistachio cultivation in Iran in 2003 is allocated to 
about 66 percent of the total land under cultivation of pistachios in the world alone it is the first place the Turkey with 40 thousand, 35 thousand of America and Tunisia with 23 thousand hectares were allocated respectively second, third and fourth positions. Based on reported Gulf Group International Economics statistics published the Census Bureau U.S. Department of Agriculture shows that in the current year, Iran has been produced 210 thousand tons of Pistachio that this number has been increased to 25 thousand tons in years ago. In 2008 due to drought, pistachio production in Iran was decreased to one third and reached 90 thousand-ton but in 2009 this number has increased to 185 thousand tons and also in the current year has reached to 210 thousand tons. Based on this report, according to that Iran is largest producer of pistachios in the world, in current year has been in the second after the U.S. American pistachios production has been reported to 236 thousand tons and this while never American pistachios production did not exceed from 190 thousand tons and in this country pistachios production reached to 161 thousand tons in last year (2009-2010). Based on statistics U.S. Department of Agriculture according to production of 236 thousand tons in this country, Pistachio production in current year has reached to 632 thousand tons that 33 percent of this number is related to Iran.

Turkey with 110 thousand tons, Syria with 65 tons and the Europe Union with 10 tons are other world producers of pistachios and this report has introduced Iran as largest pistachios exporter in the world. In current year Iran has exported 160 thousand tons pistachios and thus has been placed in first rank so that in this year Iran's pistachios exports has been increased to 31 thousand tons than last year. America with 150 thousand tons place in second rank and Syria with 10 thousand tons, Europe Union with 1600 tons and Turkey with 1000 tons places in other ranks. Total world pistachios exports have been 322 thousand tons that 50 percent of this number is related to Iran's production. Europe Union with 80 thousand tons was introduced largest pistachios importer in current year and China with 55 thousand tons and Hong Kong with 50 thousand tons has placed in second and third ranks.

Table 1: Acreage pistachios in the world, Iran and 9 major producing countries in the year's 1990 to2003, Unit: thousand hectares

\begin{tabular}{|c|c|c|c|c|c|c|c|c|c|c|c|c|c|c|}
\hline 2003 & 2002 & 2001 & 2000 & 1999 & 1998 & 1997 & 1996 & 1995 & 1994 & 1993 & 1992 & 1991 & 1990 & Country \\
\hline 432 & 440 & 417 & 407 & 394 & 402 & 386 & 373 & 356 & 344 & 338 & 312 & 291 & 275 & World \\
\hline 285 & 295 & 280 & 274 & 256 & 259 & 247 & 231 & 218 & 206 & 201 & 171 & 161 & 154 & Iran \\
\hline 35 & 33 & 31 & 30 & 29 & 27 & 26 & 26 & 24 & 23 & 23 & 22 & 22 & 21 & America \\
\hline 40 & 40 & 36 & 36 & 37 & 37 & 36 & 34 & 34 & 33 & 32 & 31 & 30 & 29 & Turkey \\
\hline 20 & 20 & 18 & 18 & 19 & 20 & 18 & 18 & 15 & 14 & 13 & 21 & 17 & 14 & Syria \\
\hline 15 & 15 & 15 & 12 & 15 & 17 & 17 & 16 & 16 & 16 & 16 & 16 & 16 & 16 & China \\
\hline 5 & 5 & 5 & 5 & 5 & 5 & 5 & 5 & 4 & 5 & 4 & 4 & 3 & 3 & Greece \\
\hline 3 & 3 & 3 & 3 & 3 & 3 & 3 & 4 & 3 & 3 & 3 & 3 & 3 & 3 & Italy \\
\hline 2 & 2 & 2 & 2 & 2 & 2 & 2 & 2 & 2 & 2 & 2 & 2 & 2 & 2 & Afghanistan \\
\hline 23 & 23 & 21 & 21 & 21 & 24 & 26 & 28 & 32 & 35 & 38 & 36 & 33 & 27 & Tunisia \\
\hline 0.66 & 0.67 & 0.67 & 0.67 & 0.65 & 0.64 & 0.64 & 0.62 & 0.61 & 0.60 & 0.59 & 0.55 & 0.55 & 0.56 & $\begin{array}{l}\text { Iran's share } \\
\text { of world }\end{array}$ \\
\hline
\end{tabular}

Source: Organization United Nations Food and Agriculture

Also in Iran during these 5 years (1999-2003), survey production process of pistachios input shows status of drop and the seismicity. FAO reported that volume of pistachios production in Iran during years after the revolution victory has not the specific trend such as 303 thousand tons production of pistachios in 2000 has decreased to 112 thousand tons suddenly in 2001 and again in 2002 has increased to 249 thousand tons. Based on this report other sample of this power fluctuation is Iran's pistachios production in 1996 year so that in this year pistachios 260 thousand tons production has decreased to 111 thousand tons in 1997 year and in 1998 year was faced to increasing 200 percent and reached to 313 thousand tons while in 1987 year (in the revolution victory year) has been 69 thousand tons and two years later has decreased about 20 thousand tons but again in 1981 year has reached to 122 thousand tons and also in 1982 year has decreased to 96 thousand tons. 
Table 2: Production rate of pistachios in the world and ten of the nation's leading manufacturer during the years 1990-2002, Unit: tons

\begin{tabular}{cccccccccccccc}
\hline $\mathbf{2 0 0 2}$ & $\mathbf{2 0 0 1}$ & $\mathbf{2 0 0 0}$ & $\mathbf{1 9 9 9}$ & $\mathbf{1 9 9 8}$ & $\mathbf{1 9 9 7}$ & $\mathbf{1 9 9 6}$ & $\mathbf{1 9 9 5}$ & $\mathbf{1 9 9 4}$ & $\mathbf{1 9 9 3}$ & $\mathbf{1 9 9 2}$ & $\mathbf{1 9 9 1}$ & $\mathbf{1 9 9 0}$ & Country \\
\hline 581974 & 293687 & 566238 & 459262 & 511347 & 32738 & 434094 & 394107 & 343681 & 397880 & 348306 & 329544 & 273080 & World \\
28000 & 26000 & 22000 & 29000 & 26000 & 30000 & 2800 & 25000 & 25000 & 24000 & 21500 & 23000 & 22000 & China \\
8500 & 7500 & 6500 & 6000 & 8072 & 937 & 8892 & 5591 & 5351 & 5573 & 4786 & 4989 & 3439 & Greece \\
24900 & 112432 & 303957 & 290017 & 313957 & 111916 & 260085 & 238778 & 195000 & 229332 & 201632 & 182484 & 162831 & Iran \\
1887 & 1762 & 2768 & 2649 & 512 & 5000 & 100 & 2200 & 240 & 1799 & 156 & 2400 & 200 & Italy \\
137440 & 73030 & 110220 & 55790 & 85280 & 81900 & 47630 & 67130 & 58500 & 68950 & 66680 & 34936 & 54430 & America \\
52840 & 37436 & 39923 & 30133 & 35684 & 29428 & 24324 & 14538 & 14925 & 13700 & 20200 & 14400 & 13000 & Syria \\
35000 & 30000 & 75000 & 40000 & 35000 & 70000 & 60000 & 36000 & 40000 & 50000 & 29000 & 64000 & 14000 & Turkey \\
200 & 196 & 209 & 194 & 238 & 238 & 200 & 200 & 210 & 230 & 285 & 361 & 250 & Pakistan \\
800 & 1100 & 1600 & 1200 & 1200 & 1200 & 1000 & 900 & 900 & 900 & 800 & 620 & 600 & Tunisia \\
\hline
\end{tabular}

Source: United Nations Food and Agriculture Organization

The table below shows that pistachios market is almost exclusive but this monopoly is being loss. If Iran can be increase his share in world markets thus it can be operate as a monopolist largely. Of course it obvious that creating, maintenance and proper use of this monopoly is subject to creating unions and formation of strong export that should be had Coordination and planning necessary. Based on results obtained in table 3 is specified that America and Syria (by increasing production) and Germany (by again export) are including major countries that their shares in world pistachios export has been growing but share of Turkey has been declining. America and especially in countries such as South America, South East Asia, Europe, Canada and some unions are expanding their pistachios market, Germany is also dedicated to her the more value-added export products by re-export (Price elasticity is higher due to higher prices for products in re-exports of services performed on goods thus impact of price fluctuations on these exports is greater). Considering that America is a lower quality of pistachios from Iran the country has tried to expand its exports through the negative action against Iranian Pistachio: first, to infect Iran's pistachio named Aflatoxin and second ways to purchase Iranian Pistachio and sell its products to various markets in America in order to create a mentality of peer quality pistachio of Iran and America in the minds of foreign consumers.

Table 3: A major exporter of pistachios in the world and the export value during 2000-2003

\begin{tabular}{ccccccccl}
\hline & \multicolumn{7}{c}{ Share(percent) } & \multicolumn{6}{c}{ Export value(million dollars) } & \multirow{2}{*}{ Country } \\
\cline { 1 - 6 } $\mathbf{2 0 0 3}$ & $\mathbf{2 0 0 2}$ & $\mathbf{2 0 0 1}$ & $\mathbf{2 0 0 0}$ & $\mathbf{2 0 0 3}$ & $\mathbf{2 0 0 2}$ & $\mathbf{2 0 0 1}$ & $\mathbf{2 0 0 0}$ & \\
\cline { 1 - 6 } $\mathbf{7 0 . 2}$ & 64.6 & 58 & 60 & 680 & 436.5 & 359 & 314.2 & Iran \\
$\mathbf{9 . 4}$ & 11.7 & 11.5 & 12 & 91 & 79 & 71 & 63 & United States of \\
& & & & & & & & America \\
$\mathbf{5}$ & 7.4 & 10 & 9 & 48 & 50.3 & 61.6 & 47 & Germany \\
$\mathbf{4}$ & 4.6 & 3.5 & 5 & 37.5 & 31.1 & 21.5 & 26.2 & Luxembourg \\
$\mathbf{1 . 8}$ & 2.2 & 5.3 & 7 & 17.4 & 15 & 33 & 36 & Hong Kong \\
$\mathbf{3 . 7}$ & 0.9 & 0.34 & 0.3 & 36 & 6 & 2.1 & 1.5 & Netherlands \\
$\mathbf{1 0 0}$ & 100 & 100 & 100 & 966 & 676 & 619 & 524 & Total exports \\
\hline
\end{tabular}

Source: United Nations Statistics Division

\section{Literature review}

Hamuda, Elbeidi and Gazda (2010) studied the relationship between export and economic growth the using time-series data of 1980-2007 in Libya Arabic Union. Results showed that in the short term export growth has positive effect on Gross Domestic product (GDP) growth. Export, GDP and exchange rate are converging and there is long-term bilateral relationship between export and GDP growth. Pandey (2006) in his article reviewed export and Economic Growth by causality relationship the using time-series data of 1950-2002 in India. He used the following model:

$$
\begin{aligned}
& Y_{t}=a+\sum_{i=1}^{m} \alpha_{1} Y_{t-1}+\sum_{i=1}^{n} \alpha_{2} X_{t-1}+U_{t} \\
& X_{t}=b+\sum_{j=1}^{k} \beta_{1} X_{t-1}+\sum_{j=1}^{k} \beta_{2} Y_{t-1}+V_{t}
\end{aligned}
$$

Where $\mathrm{Y}$ is GDP and $\mathrm{x}$ is exports.

Result show that in short term there is bilateral relationship between exports and GDP and in the long term exports and GDP aren't convergent in constant prices but are convergent in current prices. Jordan (2007) in his article studied exports and Economic Growth the using time-series data of 1970-2005 in Namibia. He used the following models 


$$
\begin{aligned}
& \text { Export }_{t}=\sum_{j=1}^{p} \alpha_{j} \text { Export }_{t-j}+\sum_{j=1}^{p} G D P_{t-j}+U_{t} \\
& G D P_{t}=\sum_{j=1}^{p} \alpha_{j} \text { Export }_{t-j}+\sum_{j=1}^{p} Y_{j} G D P_{t-j}+V_{t}
\end{aligned}
$$

The result showed that exports in the short term lead to economic growth. Also, there is positive longterm relationship between exports and economic growth. Shan and Sun (1998) studied causal relationship between exports and growth the using time-series data of 1996-1978 in Hong Kong, Korea and Taiwan by VAR method and they have used the Matrix model. Their results showed that there is a two-way relationship between exports and economic in Hong Kong and Korea but for Taiwan lead to economic growth only by export. Esfahani (1999) showed that extrovert policies are key to long-term national development. He argued about the relationship between exports and economic growth in less developed countries. His empirical shows that difference between the lack of currency resources and side effects of extrovert policies are only the result of exports promotion policies. Bakhtiari and Haghi (2001) have worked on the effects of oil incomes on Iran's agricultural sector. Then empirical finally shows that the impact of oil incomes among 1974-1977 resulted in a phenomenon called anti-agricultural. Sachs \& Warner (2001) showed positive relationship between natural resources and general level of prices for 99 countries during 1970 to 1980 as another description of economic poor performance of countries that own natural resources. Papapetrou (2001) in his essay works on the impact of oil shocks on employment and economical activities in Greece used VAR model to show that there is a long term relationship between oil price, GDP and employment in Greece.

Leaderman \& Maloney (2003) by using Learman (1984) empirical model find a positive relationship between natural resources and economic growth by measuring natural resources. Pahlavani (2005) conducted a research on relationship between exports and economic growth by applying co-integration technique. In his research he used Feder applied model in his estimations and showed the effects of structural breaks on macro variables of Iran's economic growth.

\section{Methodology}

In initial studies conducted regardless of the characteristics, time series variables and hypothesis of stationary variables has been performed time series analysis while recent developments in time series analysis showed that most macroeconomic series are non-stationary accordingly these series are named difference stationary. In this study time series have considered because of stationary hypothesis. Due to determine order the mass of variables we have tested unit root by Dickey Fuller (DF) and Augmented Dickey Fuller (ADF) tests. ADF test states that is every series stationary by performed Ordinary Least Square (OLS) regression?

In Auto Regressive Distributed Lag pattern is used (ARDL) model for survey being long term equilibrium relationship. Consider the following dynamic model:

$\mathrm{A}(\mathrm{L}) \mathrm{y}_{\mathrm{t}}=\mathrm{B}(\mathrm{L}) \mathrm{x}_{\mathrm{t}}+\mathrm{u}_{\mathrm{t}}$

In this relation:

$$
\begin{aligned}
& A(L)=1-a_{1} L-a_{2} L^{2}-\ldots \ldots a_{p} L^{p} \\
& B(L)=\gamma_{0}+\gamma_{1} L+\gamma_{2} L^{2}+\ldots . \gamma_{q} L^{q} \\
& L^{\gamma}=\chi_{t-\gamma} \\
& \hat{\beta}=\frac{\sum_{i=0}^{q} \hat{\gamma}_{q}}{1-\sum_{i=0}^{q} \hat{a}_{i}}
\end{aligned}
$$

This pattern is named Auto Regressive Distributed Lag and optimum lags number is determined by one of the Schwarts-Bayesian, Akaike, Hannan-Quinn and $\mathrm{R}^{2}$ criteria. In this pattern if sum of variables coefficients with lag related to dependent variable be less, dynamic model will tend toward equilibrium model of long-term so that is tested including: 


$$
\begin{aligned}
& H_{\mathrm{O}}: \sum_{t=1}^{p} a_{t}-1 \geq 0 \\
& H_{1}: \sum_{t=1}^{p} a_{t}-1 \prec \mathrm{O}
\end{aligned}
$$

The quantity $\mathrm{t}$ statistic required to test the above is calculated as the following:

$$
\boldsymbol{t}=\frac{\sum_{t-1}^{p} \hat{a}_{t}-\mathbf{1}}{\sum_{t-1}^{p} \boldsymbol{s}_{\hat{a}_{t}}}
$$

Provided a critical quantity by Banerjee, Dolado and Master (1993) the confidence level $95 \%$ is equal to 3.82 .

Error correction model: Error correction models are patterns that contact fluctuations short-term variables to their equilibrium values. If be a long term equilibrium relationship between two variables accumulated Xt and Yt as:

$$
y_{t}=\alpha \chi_{t}+u_{t}
$$

Thus in short term sentence error in this equilibrium is called the equilibrium error. For to associate treat short term Yt to long term equilibrium values, consider the following pattern:

$$
\begin{aligned}
& \Delta y_{t}=\beta_{\mathrm{O}}+\beta \Delta \chi_{t}+\beta_{2} \hat{u}_{t-1}+\varepsilon_{t} \\
& \varepsilon_{t} \approx \boldsymbol{I I D}\left(\mathrm{O}, \delta^{2}\right)
\end{aligned}
$$

Where, Ut-1 is sentence estimating error in regression function (9) with one time lag. Model (10) is called Error Correction Model (ECM). According to Xt and Yt are one rank collective and accumulated thus can say that series Ut is stationary and consequently all variables in function (7) are I (0) thus is used estimation ECM by Ordinary Least Square (OLS) method and in addition F and t statistics have credit statistic (Noferesti). Data for exports, population, Gross Domestic Product (GDP), standard Index and exchange rate are annual and obtained from the Central Bank of Iran and the Islamic Republic of Iran Customs Administrations. Variables are in natural log and in constant dollar (2000). They are:

OILEX is oil export, PEX is real pistachio export, GDP is measured as Gross Domestic Product, SI is standard index and EXCH is exchange rate in Iran. Exports are subtracted GDP for avoiding exports biasness and the spurious correlation between exports and growth. With these variables, the paper estimates the following simple model:

$$
L G D P_{t}=C+\beta_{1} L P E X_{t}+\beta_{2} L O I L E X_{t}+\beta_{3} L S I_{t}+\beta_{4} L E X C H_{t}+\beta_{5} D U 76+\beta_{6} D U 99+\varepsilon_{t}
$$

This paper uses Error Correction Model (ECM) estimates and Augmented Dickey Fuller (ADF) tests for finding causal relation and the direction of causality. Where $\mathrm{T}$ denotes the time trend and the failure to reject the null hypothesis of unit root $(\rho=1)$ signifies the existence of a non-stationary process.

\section{Results}

Unit root test by Augmented Dickey - Fuller (ADF): The result of the ADF test is provided in Table 4. Second, the cointegration properties of the variables are examined using Pesaran based co-integration ARDL test. Results of Co-integration test is provided in Table 5.

Table 4: Result of unit root test by Augmented Dickey-fuller (ADF)

\begin{tabular}{rcccc}
\hline \multirow{2}{*}{ variables } & \multicolumn{2}{c}{ Without trend } & \multicolumn{2}{c}{ With trend } \\
\cline { 2 - 5 } & level & First diff. & level & First diff. \\
\hline GDP & -2.54 & -4.41 & -2.06 & -5.05 \\
OIL EX & -1.35 & -8.97 & -1.71 & -4.13 \\
PEX & -1.39 & -9.19 & -1.92 & -6.51 \\
SI & -2.29 & -8.04 & -2.03 & -7.62 \\
EXCH & -1.45 & -10.39 & -1.19 & -11.38 \\
\hline
\end{tabular}


The significance of the Error Correction Term and F-statistics, in Table 5, indicates causal and long term relation among the variables in Iran.

Long-term test: Exist or non-exist long-term relationship between the dependent variable and other explanatory variables can be examined using the F test. We use to estimate ARDL long-run coefficients based on analysis of Pesaran and Smith (1998), the criterion of Schwartz - Bayesian.

Table 5: Estimated long-run coefficients ARDL

\begin{tabular}{lcc}
\hline \multicolumn{1}{c}{ Regresses } & Coefficient & t-Ratio(prob) \\
\hline OIL EX & 0.16 & $5.22[000]$ \\
PEX & 0.39 & $1.69[000]$ \\
SI & 0.09 & $8.34[000]$ \\
EXCH & 0.18 & $5.91[000]$ \\
Intercept & 3.5 & $0.86[006]$ \\
DU76 & -0.17 & $-5.37[000]$ \\
DU99 & -0.12 & $-5.45[000]$ \\
& $\mathrm{F}=7.24[000]$, D.W $=2.07$ \\
\hline
\end{tabular}

Note: The Schwartz Bayesian Criterion (SBC) is used to select the optimum number of lag in the ARDL model.

Empirical results in Table 5 show that a one percent increase in pistachio export leads to 0.39 percent increase in Gross Domestic Product (GDP). Our empirical finding shows negative relationship and meaningful between structural break of drought (1999) and war at 1976 with Gross Domestic Product (GDP).

Short-term and error correction test: We've selected the value 2 for Maximum log length in ARDL model; also we used F statistics for the variables of OIL EX, PEX, SI and EXCH dependent variable. In all these cases, the F statistics value falls below of the lower range and the zero hypotheses cannot reject. Therefore we consider GDP as dependent variable. Calculated F statistics (GDP as dependent) have been equaled to 2.79. According to Pesaran (2000) model it is placed between the upper and lower limit at 5 percent, therefore it is used of Error Correction (ECM) model between variables to determine long-term relationships. The results of short-term test show that stability tests are meaningful and their all coefficient are exceed the $\% 5$. Therefore be rejected Functional form problem. The results obtained from the estimate of ECM have been illustrated on Table 6.

Table 6: Estimated Error Correction Model

\begin{tabular}{ccc}
\hline Regresses & Coefficient & t-Ratio(prob) \\
\hline DOIL EX & 0.19 & $5.4[000]$ \\
DPEX & 0.42 & $1.44[000]$ \\
DSI & 0.12 & $4.63[001]$ \\
DEXCH & 0.15 & $1.69[000]$ \\
DC & 4.06 & $0.77[008]$ \\
DDU76 & -0.19 & $-0.62[000]$ \\
DDU99 & -0.15 & $-0.54[000]$ \\
ECM(-1) & -0.36 & $-6.54[001]$ \\
\hline
\end{tabular}

The error correction term shows a long term relationship between model variables. Bannerjee et al. (1998) holds that a highly significant error correction term is further proof of the existence of a stable long-term relationship. Table 6 shows that the expected negative sign of the ECM is highly significant the estimated coefficient of the ECM ( -1$)$ is equal to -0.36 , suggesting that deviation from the long-term Gross Domestic Product (GDP) path is corrected by 0.36 percent over the following year. This means that the adjustment takes place relatively slowly.

\section{Conclusion and Recommendations}

Iran as the dominant firm holds about 60 percent of global pistachio export. Also comparative advantage of its export has too many differences with the other pistachio exporter but despite a top position in global exports of pistachios, does not have effective role in determining the export price. So that Iran pistachio export prices is low compared to other exporting countries that are a tiny proportion of global 
exports of pistachios. Generally, the reason can be seen as a result of weakness in the global marketing of pistachio. So recommended planning principles and specific for Packing and coordination export standards with health standards of each of the target markets be formulated by the government to take advantage of the potential of this opportunity to come forward (Having 60 percent share of global exports pistachios). Compliance with the export standard in the case of most products has positive and significant impact on their exports. Namely increasing observance international standards in the field of agricultural exports and improving quality, can attract more markets and thus expanded its foreign exchange earnings. To avoid fluctuations in export of products made should be designed a clear export strategy for these products, for access to export-oriented strategy should be developed long-term export policy and in the way achieving the targets defined in the strategy should be carried a clear and coordinated plan the encompasses all the relevant agencies. This performance is achieved through the use of high product variety and customer friendly. The other part, reform of laws troubling export improving Health Products for export and providing infrastructure for export such as transportation, packaging, processing and laboratory systems that their realization is possible by encouraging government and private sector investment.

Recommendations: Buy Pistachio such fresh and dried nuts from farmers and supply in domestic and foreign markets to prevent profit-seeking marketing intermediaries and improve producer prices. To help gardeners (pistachio growers) in the field of technical knowledge required and also give their required inputs and learning the correct usage in line improve product quality pistachios. 3) Marketing of manufactured products inside and outside the country the for this purpose pistachio Production Cooperative or cooperatives Union of farmers can do measures as follows: Absorption professionals in the field marketing and sending them to different regions country and world in order to establish a close relationship with internal and external customers and close contracts required to supply pistachio to them. In this context are appropriate sending good examples of pistachio with attractive packaging with these people. Provide good examples with proper and attractive packaging and send them to other countries along with other export goods to their in line do advertising and find market.

\section{References}

Bakhtiari, S., \& Haghi, Z. (2001). The effect of increase in oil incomes on agricultural sector in Iran. Quarterly Journal of EQTESAD-E KESHAVARZI VA TOWSE'E, 9(35), 109-138.

Banerjee, A., Dolado, J., Galbraith, J., W., \& Hendry, D., F. (1993). Co-integration, Error Correction and the Econometric Analysis of Non-Stationary Data. Oxford: Oxford University Press.

Banerjee, A., J., Dolado J., \& Mestre R. (1998). Error-correction mechanism tests for cointegration in a single-equation framework. Journal of Time Series Analysis, 19, 267-83.

Esfahani, H., S. (1999). Export, Imports and Economic Growth in semi. Industrialized Countries Journal of Development Economics, 35, 93-116.

Export Promotion Center of Iran 'EPCI' Different Reports between 2001 and 2002.

Feder, G. (1982). On Exports and Economic Growth. Journal of Development Economics, 12, 59-73.

Hamuda, A., M., Elbeidi, R., M., \& Vladimir G. (2010). The Relationship between Export and Economic Growth in Libya Arab Jamahiriya. Theoretical and Applied Economics, 27(1), 69-76.

Jordan, A., C. (2007). Eita Joel Hinaunye Export and Economic Growth in Namibia: A Granger Causality Analysis. South Africa Journal of Economic, 25, 540-547.

Leaderman, D. \& Maloney, W., F. (2003). Trade Structure and Growth, World Bank Policy Research Working Paper, 3025.

Leamer, E. (1984). Sources of Comparative Advantage, Theory and Evidence. Cambridge Massachusetts: MIT Press.

Pahlavani, M. (2005). Sources of Economic Growth in Iran: A Co-integration analysis in the presence of structural breaks. Applied Econometrics and international Development, 5(4), 83-94.

Pahlavani, M., Valadkhani, A. \& Worthington, A. (2005). The Impact of Financial Deregulation on Monetary Aggregates and Interest Rates in Australia . Applied Financial Economics Letters, 1(3), 157-163.

Panday, A., K. (2006). Export and Economic Growth in India: Causal Interpretation. Journal of Global Economy, 2, 245-277.

Papapetrou, E., (2001). Oil price shocks, stock market, economic activity and employment in Greece. Energy Economics, 23(5), 511-532.

Pesaran, M., H. (2000). Economic Trends and Macroeconomic Policies in Post Revolutionary Iran. Journal of Money and Banking, 1(2), 26-66. 
Pesaran, M. H. \& Smith, R. (1998). Structural analysis of cointegrating VARs. Journal of Economic Surveys 471-506. Also published in L. Oxley and M. McAleer (eds) Practical Issues in Co-integration Analysis, (1999), chapter 3, Oxford, Basil Blackwell. ISBN 0631211985.

Sachs, J. \& Warner, A. (2001). Natural Resource Abundance and Economic Development, The Curse of Natural Resources. European Economic Review, 45, 827-838.

Shan, J. \& Sun, F. (1998). On the Export-led Growth Hypothesis for the little Dragons: An Empirical Reinvestigation. Atlantic Economic Journal, 26 (4), 353-371. 